\title{
PERANCANGAN DISASTER RECOVERY PLAN (DRP) UNTUK MENINGKATKAN KETERSEDIAAN LAYANAN SISTEM PEMERINTAHAN BERBASIS ELEKTRONIK (SPBE) PADA BADAN STANDARDISASI NASIONAL
}

\section{Design of Disaster Recovery Plan (DRP) to improve availability of E-Government services in National Standardization Agency of Indonesia}

\author{
Rizky Mulya Akbar, Anang Tri Setyo Utomo, Yopi Prasetya Haeroni \\ Pusat Data dan Sistem Informasi, Badan Standardisasi Nasional \\ Jl.MH Thamrin No.8, Jakarta Pusat \\ email : rissqy@gmail.com
}

\begin{abstract}
Abstrak
Pelaksanaan sistem pemerintahan berbasis elektronik (SPBE) di lingkungan Badan Standardisasi Nasional (BSN) merupakan upaya mewujudkan pelayanan publik yang berkualitas dan terpercaya. Penerapan SPBE ini mendukung BSN dalam memberikan pelayanan terhadap masyarakat melalui pemanfaatan teknologi informasi dan komunikasi, sehingga membuat data dan informasi menjadi bagian yang penting bagi BSN. Permasalahannya ialah risiko kehilangan akses data dan informasi akibat bencana yang mungkin terjadi setiap saat, maka dari itu Pusat Data dan Sistem Informasi (Pusdatin) yang merupakan salah satu unit kerja di BSN yang memilki tanggung jawab terhadap pengelolaan data center yang merupakan sumber utama dari data dan informasi perlu merancang Disaster Recovery Plan (DRP) yaitu sistem perencanaan keberlangsungan pelayanan untuk menanggulangi gangguan atau bencana sesuai dengan risiko dari dampak yang ditimbulkannya. DRP disusun untuk mempersiapkan pencegahan terjadinya kerusakan dan kehilangan data, informasi dan sistem, serta mempersiapkan tindakan penanganan dan pemulihan bila terjadi kerusakan sistem yang berdampak pada ketersediaan layanan sistem elektronik.
\end{abstract}

Kata kunci:, Disaster Recovery Plan (DRP), Sistem Pemerintahan Berbasis Elektronik (SPBE), Analisis Dampak Bisnis.

\begin{abstract}
The implementation of E-Government within the National Standardization Agency (BSN) is an effort to realize quality and reliable public services. The application of this SPBE supports BSN in providing services to the community through the use of information and communication technology, thus making data and information an important part of BSN. The problem is the risk of losing access to data and information due to disasters that may occur at any time, therefore the Data Center and Information System (Pusdatin) which is one of the work units in $B S N$ that has responsibility for managing the data center which is the main source of data and information needs to design a Disaster Recovery Plan (DRP) which is a service continuity planning system to deal with disruptions or disasters in accordance with the risk of the impacts they cause. DRP is prepared to prepare for the prevention of damage and loss of data, information and systems, as well as prepare for handling and recovery measures in the event of system damage that affects the availability of electronic system services.
\end{abstract}

Keywords : Disaster Recovery Plan (DRP), e-government, business impact analysis (BIA)

\section{PENDAHULUAN}

\section{Latar Belakang}

Pelaksanaan sistem pemerintahan berbasis elektronik (SPBE) di lingkungan Badan Standardisasi Nasional (BSN) merupakan upaya mewujudkan pelayanan publik yang berkualitas dan terpercaya. Penerapan SPBE ini mendukung BSN dalam memberikan pelayanan terhadap masyarakat melalui pemanfaatan teknologi informasi dan komunikasi, sehingga membuat data dan informasi menjadi bagian yang penting bagi
BSN. Upaya yang dilakukan BSN melalui Pusat Data dan Sistem Informasi (Pusdatin) adalah menjaga ketersediaan informasi dalam pelayanan publik. BSN memiliki data center yang dikelola oleh Pusdatin yang sampai saat ini mampu menangani dan menampung seluruh sistem elektronik yang digunakan oleh unit kerja di lingkungan BSN.

Data center diharapkan mampu memberikan operasi yang berkelanjutan dan terusmenerus baik dalam keadaan normal maupun dalam keadaan terjadinya suatu kerusakan yang berarti atau tidak. 
Seiring berjalannya waktu, Pusdatin sebagai pengelola data center tidak tahu akan adanya kejadian-kejadian yang tidak bisa diprediksi dan bersifat sangat merusak. Berbagai bencana yang mungkin terjadi antara lain adalah bencana alam, kebakaran, kerusakan pada jaringan listrik, serangan teroris, sistem atau perangkat yang rusak, kesalahan operasional atau virus, bisa menyebabkan kerusakan pada Data Center. Oleh karena itulah perlu dirancang Disaster Recovery Plan (DRP). DRP memberikan langkah-langkah pada organisasi jika kejadian bencana timbul. DRP akan mengurangi kebingungan yang terjadi saat ada bencana dan meningkatkan kemampuan organisasi saat menghadapi keadaan krisis.

\section{Tujuan}

Sesuai dengan latar belakang di atas, maka tujuan penelitian ini ialah "Merancang Disaster Recovery Plan" yang memiliki tujuan yaitu :

1. Melindungi organisasi dari kegagalan sistem utama

2. Meminimalisasi risiko organisasi terhadap penundaan (delay) dalam penyediaan layanan

3. Menjamin kehandalan dari sistem yang sedia melalui pengetesan dan simulasi

4. Meminimalisasi proses pengambilan keputusan oleh personal/manusia selama bencana.

\section{TINJAUAN PUSTAKA}

\section{Data Center / Pusat Data}

Kumpulan server dan system penyimpanan data membutuhkan fasilitas untuk menampung semua sumber daya yang dimiliki. Fasilitas tersebut harus memenuhi kondisi server yang memungkinkan untuk melakukan pengaturan sumber daya, pengaturan udara serta memiliki system pengamanan fisik. Fasilitas yang menjadi pusat penampungan data (Data center) ini memiliki beberapa kriteria khusus dalam perancangannya, antara lain :

1. Availability, Data center mampu menjalankan operasi

berkelanjutan dan terus menerus dalam kondisi apapun.

2. Scalability dan Flexibility, Data Center mampu beradaptasi dengan pertambahan kebutuhan atau teknologi baru tanpa merubah substansi data center secara keseluruhan.
3. Security, Data Center mampu melindungi asset data yang tersimpan pada server secara fisik maupun non-fisik.

Disaster Recovery Plan

Disaster Recovery Plan adalah suatu acuan berisikan prosedur untuk merespon kejadian yang mengakibatkan hilangnya sumber daya sistem informasi secara bermakna (bencana), menyediakan operasi cadangan selama sistem terhenti, dan mengelola proses pemulihan serta penyelamatan sehingga mampu meminimalisir kerugian yang dialami oleh organisasi. Tujuan utama dari Disaster Recovery Plan adalah untuk menyediakan kemampuan atau sumber daya untuk menjalankan proses vital untuk meminimalisir kerugian organisasi. Karena bertindak sebagai pegangan saat terjadi keadaan darurat, Disaster Recovery Plan tidak dapat disusun secara sembarangan. Disaster Recovery Plan yang tidak sesuai dapat berakibat lebih buruk bagi keberlangsungan organisasi daripada bencana itu sendiri. Proses pembangunan Disaster Recovery Plan disebut Disaster Recovery Planning.

\section{Bencana}

Menurut (S. Arie Priambodo, 2009) bencana adalah suatu kejadian alam, buatan manusia, atau perpaduan antara keduanya yang terjadi secara tiba-tiba sehingga menimbulkan dampak negatif yang dahsyat bagi kelangsungan kehidupan. Dalam kejadian bencana tersebut, unsur yang terkait langsung atau terpengaruh harus merespons dengan melakukan tindakan perbaikan guna menyesuaikan sekaligus memulihkan kondisi seperti semula atau menjadi lebih baik.

Bencana dalam hubungannya dengan Disaster Recovery Planning adalah segala sesuatu yang menggangu berjalannya proses bisnis sehingga menghambat suatu organisasi dalam menjalankan fungsinya. Bencana umumnya dianggap melumpuhkan jika bencana tersebut meniadakan salah satu atau lebih sumber daya berikut:

1. Sumber daya manusia

2. Fasilitas

3. Komunikasi

4. Daya

5. Akses Informasi 
Klasifikasi Bencana

Menurut (Snedaker, 2007), kriteria ancaman dibagi kepada 4 tipe ancaman, diantaranya adalah:

\section{Natural / Environtmental Threats}

Merupakan ancaman yang disebabkan oleh bencana alam, atau gangguan yang terjadi secara natural. Contoh ancamannya antara lain adalah, fire; flood; storm; earthquake; pandemic.

\section{Human-caused Threats}

Merupakan ancaman yang disebabkan oleh ulah manusia. Contoh ancamannya adalah theft, sabotage, vandalism; labor disputes; terrorism; civil unrest.

3. Infrastructure Threats

Merupakan ancaman yang disebabkan adanya kerusakan ataupun gangguan dari segi infrastruktur perusahaan. Contoh ancamannya adalah building specific failure; non-IT equipment failure; heating/cooling failure; electricity failure.

4. IT-Specific Threats

Merupakan ancaman yang disebabkan oleh sistem teknologi informasi. Contoh ancamannya antara lain cyber threat; virus, worm, malware; system failure.

Sedangkan berdasarkan dampaknya, bencana dapat dibedakan menjadi tingkatan risiko yang berbeda-beda. Tingkatan risiko ini juga dikenal sebagai The Five Layer of Risk, yang didefinisikan sebagai berikut:

\section{Layer 1: External Risks}

Dampak bencana yang timbul tidak hanya mempengaruhi fasilitas, aset, dan lokasi organisasi tetapi juga lingkungan sekitar organisasi. Umumnya disebabkan karena bencana alam, seperti banjir, gempa, dan lain sebagainya.

\section{Layer 2: Facility Wide Risks}

Dampak bencana yang timbul hanya mempengaruhi organisasi saja secara lokal. Umumnya disebabkan karena tidak tersedianya utilitas dasar yang diperlukan oleh organisasi tersebut, seperti listrik, jaringan telepon, dan lainnya.

3. Layer 3: Data System Risks

Dampak bencana yang timbul mempengaruhi ketersediaan dan integritas dari data dan sistem informasi yang digunakan oleh organisasi tersebut. Umumnya disebabkan karena faktor kerusakan atau intrusi pada sistem keamanan jaringan/data yang digunakan.

\section{Layer 4: Departemental Risks}

Dampak bencana yang timbul hanya mempengaruhi satu atau beberapa bagian dari organisasi, sehingga organisasi hanya mengalami dampak tidak langsung, seperti tidak tetapi juga lingkungan sekitar organisasi. Umumnya disebabkan karena bencana sosial seperti, demonstrasi karyawan di suatu cabang/departemen, dan lain sebagainya.

\section{Layer 5: Desk Risks}

Dampak bencana yang timbul hanya mempengaruhi tingkat individu/personel, tidak mempengaruhi organisasi secara langsung maupun besar. Contoh bencana dengan risiko ini antara lain: terhapusnya berkas di komputer pekerja, mengakibatkan pekerjaannya tidak dapat selesai tepat waktu.

\section{Analisa Dampak Bisnis (Business Impact Analysis)}

Proses identifikasi dan pembobotan terhadap dampak yang timbul akibat gangguan dilihat dari sudut pandang finansial maupun non finansial (Jim Burtles, 2007). Menurut NIST SP800-34, 2010 BIA adalah mengidentifikasikan dan memprioritaskan faktor-faktor kritis dalam proses bisnis organisasi. Tahapan dalam melakukan BIA :

a. Determine mission / business processes and recovery criticalit

Mengidentifikasikan dampak yang timbul terhadap gangguan sistem yang mendukung proses bisnis baik berupa penghentian proses (outage) dan perkiraan waktu henti (estimated downtime). Perkiraan waktu henti menentukan toleransi waktu maksimum saat pemulihan.

b. Identify resource requirements Mengidentifikasikan sumber daya mencakup fasilitas, personil, peralatan, software, file data, komponen sistem dan lain sebagainya guna melanjutkan proses bisnis organisasi.

c. Identify recovery priorities for system resources

Menentukan tingkatan prioritas sumber daya pada kegiatan pemulihan bisnis proses.

\section{Risk Assestment}

Risk assessment (penilaian risiko) adalah metode yang sistematis untuk menentukan apakah suatu organisasi memiliki resiko yang dapat diterima atau tidak. Risk assessment merupakan kunci dalam perencanan pemulihan bencana. 


\section{Recovery Time Objective (RTO)}

RTO didefinisikan sebagai waktu maksimum sebuah sistem untuk down sebelum adanya dampak yang tidak diinginkan dari rangkaian sistem lainnya yang mendukung proses bisnis perusahaan tersebut.

\section{Recovery Point Objective (RPO)}

RPO didefinisikan tentang jumlah toleransi minimum data dari sebuah sistem yang bisa direstorasi dari proses pemulihan yang akan dilakukan.

\section{METODE PENELITIAN}

Dalam melakukan perancangan DRP metode penelitian yang digunakan adalah melakukan studi pustaka seperti menelaah sumbersumber tertulis seperti jurnal ilmiah, buku referensi, literature serta sumber-sumber lain yang terpercaya baik dalam bentuk tulisan atau dalam format digital yang relevan dan berhubungan dengan objek yang sedang diteliti. Buku-buku dan data-data tersebut dapat dilihat pada daftar pustaka.

\section{HASIL DAN PEMBAHASAN}

\section{Identifikasi Aset}

\begin{tabular}{|c|c|c|}
\hline \multicolumn{3}{|r|}{ Identifikasi Aset } \\
\hline Aset & Kategori & Contoh \\
\hline \multirow{12}{*}{ Server } & \multirow{3}{*}{ Main Sistem Server } & Server Email \\
\hline & & Server Active Directory dan DNS Internal \\
\hline & & Server Anti Virus \\
\hline & \multirow{4}{*}{ Web Server } & Server Production \\
\hline & & Server Development \\
\hline & & Server WEB03 \\
\hline & & Server Web Pesta \\
\hline & \multirow{3}{*}{ DB Server } & Server DB SQL Server \\
\hline & & Server DB Maria \\
\hline & & Server DB Oracle \\
\hline & \multirow{2}{*}{ Additional Server } & Server File \\
\hline & & Server FTP \\
\hline
\end{tabular}

Gambar 1 Identifikasi Aset

\section{Identifikasi Aplikasi}

1. Aplikasi Pengembangan Standar

Merupakan sistem informasi untuk pengembangan standar yang meliputi pemrograman SNI, Perumusan Rancangan SNI (RSNI), Jajak Pendapat dan Penetapan SNI.

\section{Aplikasi Akreditasi}

Merupakan sistem informasi manajemen untuk layanan akreditasi lembaga penilaian kesesuaian

3. Aplikasi Pendidikan dan Pelatihan

Merupakan sistem informasi untuk layanan diklat system penilaian kesesuaian

4. Aplikasi Pemesanan Standar Online
Merupakan sistem informasi untuk layanan pemesanan standar secara daring.

5. Aplikasi Issuer Identification Number Merupakan sistem informasi untuk layanan Issuer Identification Number.

\section{Risk Assesment}

Risk assessment (penilaian risiko) adalah metode yang sistematis untuk menentukan apakah suatu organisasi memiliki resiko yang dapat diterima atau tidak. Risk assessment merupakan kunci dalam perencanan pemulihan bencana. Pada prakteknya dalam penilaian risiko Badan Standardisasi Nasional melakukan tahapan atau proses dari penetapan konteks sampai penanganan risiko yaitu :

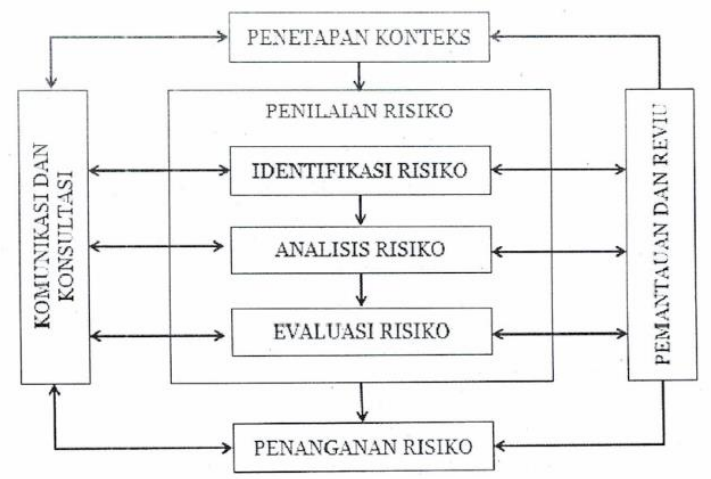

Gambar 2 Pengelolaan Risiko

Dalam penilaian risiko Badan Standardisasi Nasional memperhatikan dari beberapa aspek penilaian yaitu dari segi Level kriteria kemungkinan, Analisa risiko dari level dampak, Level risiko, dan Selera risiko.

\section{Level Kriteria Kemungkinan}

Penggunaan kriteria kemungkinan ditentukan oleh pemilik risiko (Badan Standardisasi Nasional) dengan pertimbangan :

- Presentase digunakan apabila terdapat populasi yang jelas atas kegiatan tersebut

- Jumlah digunakan apabila populasi populasi tidak dapat ditemukan.

\section{Matriks Analisa Risiko}

1. Kombinasi antara level dampak dan level kemungkinan menunjukan besaran risiko

2. Penuangan besaran risiko dilakukan dengan matriks analisis 
3. Level kemungkinan terjadinya risiko, level dampak, dan level risiko masingmasing menggunakan 5 (lima) skala tingkatan level

4. Matriks analisis risiko dan level risiko di Badan Standardisasi Nasional adalah sebagai berikut :

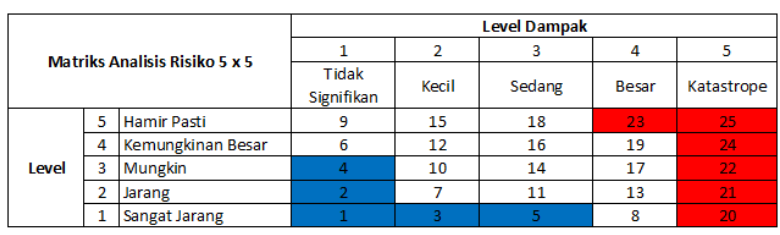

Gambar 3 Matriks Analisis Risiko

Level Risiko

\begin{tabular}{|l|c|l|}
\hline \multicolumn{1}{|c|}{ Level Risiko } & Besaran Risiko & \multicolumn{1}{c|}{ Warna } \\
\hline Sangat Tinggi (5) & $20-25$ & Merah \\
\hline Tinggi (4) & $16-19$ & Oranye \\
\hline Sedang (3) & $12-15$ & Kuning \\
\hline Rendah (2) & $6-11$ & Hijau \\
\hline Sangat Rendah (1) & $1-5$ & Biru \\
\hline
\end{tabular}

Gambar 4 Level Risiko

Selera Risiko

Selera risiko menjadi dasar dalam penetuan tolerasi risiko, yakni batasan besaran kuantitatif level kemungkinan terjadinya dan dampak risiko yang dapat di terima, sebagaimana dituangkan pada kriteria risiko. Risiko pada level rendah dan sangat rendah dapat diterima dan tidak perlu dilakukan proses mitigasi risiko, risiko dengan level sedang hingga sangat tinggi harus ditangani untuk menurunkan level risikonya.

\begin{tabular}{|c|c|l|}
\hline Level Risiko & Besaran Risiko & \multicolumn{1}{|c|}{ Tindakan Yang Diambil } \\
\hline Sangat Tinggi (5) & $20-25$ & $\begin{array}{l}\text { Diperlukan tindakan segera untuk } \\
\text { mengelola risiko }\end{array}$ \\
\hline Tinggi (4) & $16-19$ & $\begin{array}{l}\text { Diperlukan tindakan untuk mengelola } \\
\text { risiko }\end{array}$ \\
\hline Sedang (3) & $12-15$ & $\begin{array}{l}\text { Diambil Tindakan jika sumber daya } \\
\text { tersedia }\end{array}$ \\
\hline Rendah (2) & $6-11$ & Diambil tindakan jika diperlukan \\
\hline Sangat Rendah (1) & $1-5$ & Tidak diperlukan tindakan \\
\hline
\end{tabular}

Gambar 5 Selera Risiko

\section{Hasil Risk Assesment Analysis}

Dari hasil penilaian analisa risiko Badan Standardisasi Nasional mendokumentasikan beberapa risiko yang dijadikan dasar untuk dilakukan perbaikan pada beberapa risiko yang memiliki level risiko sedang sampai sangat tinggi, dalam Perancangan Disaster Recovery Plan (DRP) untuk Meningkatkan Ketersediaan
Layanan Sistem Pemerintahan Berbasis Elektronik (SPBE)

\begin{tabular}{|c|c|c|c|c|}
\hline \multirow{6}{*}{$\begin{array}{c}\text { Natural / } \\
\text { Environtmental } \\
\text { Threats (Bencana } \\
\text { Alam) }\end{array}$} & RISIKO & $\begin{array}{c}\text { Kriteria } \\
\text { Kemungkinan }\end{array}$ & $\begin{array}{l}\text { Kriteria } \\
\text { Dampak }\end{array}$ & $\begin{array}{l}\text { Nilai } \\
\text { Risiko }\end{array}$ \\
\hline & Banjir & 2 & 4 & 8 \\
\hline & Badai & 2 & 3 & 6 \\
\hline & Tsunami & 1 & 5 & 5 \\
\hline & Gempa Bumi & 2 & 3 & 6 \\
\hline & Kebakaran & 1 & 5 & 5 \\
\hline \multirow{5}{*}{$\begin{array}{l}\text { Human-caused } \\
\text { Threats (Ulah } \\
\text { Manusia) }\end{array}$} & Pencurian & 1 & 2 & 2 \\
\hline & Sabotase & 2 & 2 & 4 \\
\hline & \begin{tabular}{|l|} 
Perselisihan \\
\end{tabular} & 2 & 2 & 4 \\
\hline & Terorisme & 2 & 4 & 8 \\
\hline & Kerusuhan Sipil & 2 & 2 & 4 \\
\hline \multirow{3}{*}{$\begin{array}{c}\text { Infrastructure } \\
\text { Threats (Kerusakan } \\
\text { Infrastruktur }\end{array}$} & Kesalahan Spesifik Bangunan & 2 & 3 & 6 \\
\hline & Kegagalan Peralatan Non IT & 3 & 1 & 3 \\
\hline & Kegagalan Listrik & 3 & 4 & 12 \\
\hline \multirow{4}{*}{$\begin{array}{l}\text { IT-Specific Threats } \\
\text { (Sistem Teknologi } \\
\text { Informasi) }\end{array}$} & cyber threat & 5 & 3 & 15 \\
\hline & virus & 4 & 2 & 8 \\
\hline & \begin{tabular}{|l|} 
malware \\
\end{tabular} & 2 & 3 & 6 \\
\hline & system failure & 3 & 4 & 12 \\
\hline
\end{tabular}

Gambar 6 Analisis Risiko

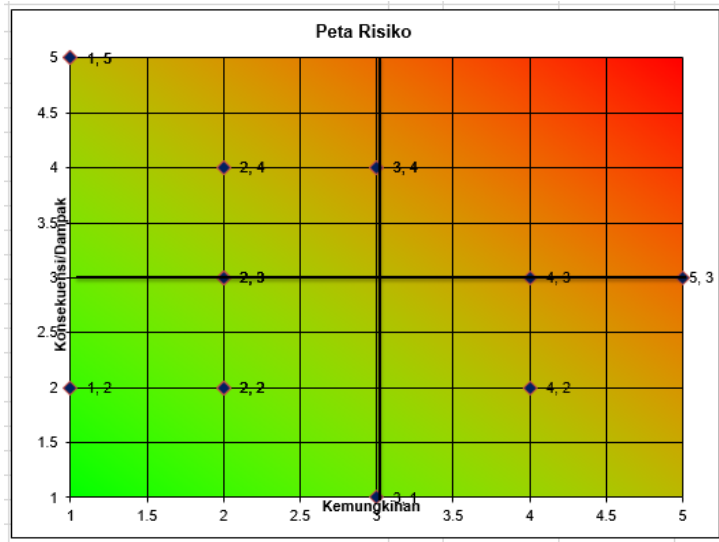

Gambar 7 Peta Risiko

\section{Hasil Analisa Dampak Bisnis}

Setelah mendapatkan hasil analisis risiko, selanjutya menjadi input untuk pelaksanaan Analisis Dampak Bisnis (Business Impact Analysis - BIA) untuk Layanan Sistem Informasi Standardisasi dan Penilaian Kesesuaian di Badan Standardisasi Nasional, berlokasi di Gedung BPPT 1, Jakarta. Analisis BIA ini didasarkan pada pandangan kuantitatif dan

kualitatif akan risiko dan eksposur atas lingkungan operasi di BSN, termasuk dampak operasional dan finansial jika BSN tidak dapat melaksanakan proses bisnisnya dan melayani masyarakat. Tujuan dari BIA ini adalah untuk membantu manajemen dengan:

1. Mengidentifikasi proses bisnis yang kritikal.

2. Menentukan Recovery Time Objective (RTO) dan Recovery Point Objective (RPO) untuk tiap proses sebelum kepuasan masyarakat dan faktor-faktor kritikal lain hancur.

3. Menyajikan rekomendasi untuk tindakan selanjutnya dalam pengembangan strategi recover yang diperlukan untuk 
mempertahankan proses bisnis yang kritikal.

\section{Proses Bisnis Kritikal}

Tabel di bawah ini dapat dijadikan rujukan untuk proses bisnis yang menjadi dasar analisis dalam mengidentifikasi proses bisnis yang kritikal untuk kemudian dijadikan sebagai bagian dari perencanan pemulihan bencana:

\begin{tabular}{|c|l|c|c|c|}
\hline No & \multicolumn{1}{|c|}{ Nama Layanan Aplikasi } & $\begin{array}{c}\text { Jumlah } \\
\text { User }\end{array}$ & $\begin{array}{c}\text { Penghasilan } \\
\text { Negara Bukan } \\
\text { Pajak / hari }\end{array}$ & $\begin{array}{c}\text { Rata-darat } \\
\text { frekuensi } \\
\text { Hits/hari }\end{array}$ \\
\hline 1 & $\begin{array}{l}\text { Sistem Informasi Standardisasi dan } \\
\text { Penilaian Kesesuaian (SISPK) }\end{array}$ & $>12000$ & & 150 \\
\hline 2 & Layanan Akreditasi & $>5000$ & Rp. 30.000 .000 & 75 \\
\hline 3 & $\begin{array}{l}\text { Layanan Pendidikan dan Pelatihan } \\
\text { SPK }\end{array}$ & $>100$ & Rp. 15.000.000 & 50 \\
\hline 4 & $\begin{array}{l}\text { Layanan Identification Issued } \\
\text { Number }\end{array}$ & $>50$ & Rp. 10.000.000 & 10 \\
\hline 5 & Layanan Pemesanan Standar & $>50$ & Rp. 10.000 .000 & 50 \\
\hline
\end{tabular}

Gambar 8 Proses Bisnis Kritikal

\section{Rekomendasi RTO \& RPO Layanan Aplikasi}

\begin{tabular}{|c|c|c|c|c|c|}
\hline \multirow[b]{2}{*}{ No } & \multirow[b]{2}{*}{$\begin{array}{c}\text { Nama Layanan } \\
\text { Aplikasi }\end{array}$} & \multirow[b]{2}{*}{\begin{tabular}{|c|} 
Rata-rata \\
frekuensi hits \\
/ waktu kerja \\
( 8 jam/hari)
\end{tabular}} & \multicolumn{3}{|c|}{ Time Frame Requirement } \\
\hline & & & $\begin{array}{l}\text { Maximum } \\
\text { Torelabe } \\
\text { Downtime } \\
\text { (MTD) }\end{array}$ & \begin{tabular}{|l} 
Recovery \\
Time \\
Objective \\
(RTO) \\
\end{tabular} & $\begin{array}{l}\text { Recovery } \\
\text { Point } \\
\text { Objective } \\
\text { (RPO) }\end{array}$ \\
\hline 1 & $\begin{array}{l}\text { Sistem Informasi } \\
\text { Standardisasi dan } \\
\text { Penilaian Kesesuaian } \\
\text { (SISPK) }\end{array}$ & 18.75 & 60 Menit & 30 Menit & 15 menit \\
\hline 2 & Layanan Akreditasi & 9.375 & 60 Menit & 30 Menit & 15 Menit \\
\hline 3 & $\begin{array}{l}\text { Layanan Pendidikan } \\
\text { dan Pelatihan SPK }\end{array}$ & 6.25 & 60 Menit & 30 Menit & 15 Menit \\
\hline 4 & $\begin{array}{l}\text { Layanan Identification } \\
\text { Issued Number }\end{array}$ & 1.25 & 180 Menit & $1 \mathrm{Jam}$ & 30 Menit \\
\hline 5 & $\begin{array}{l}\text { Layanan Pemesanan } \\
\text { Standar }\end{array}$ & 1.25 & 60 Menit & 30 Menit & 15 Menit \\
\hline
\end{tabular}

Gambar 9 RTO \& RPO

Berdasarkan table di atas maka rata-rata frekuensi hits/waktu kerja (8 jam / hari) pada aplikasi SISPK yaitu 18.75 hits/jam, sehingga ditentukan waktu untuk RTO adalah 30 menit ( 30 menit di dapatkan berdasarkan dari MTD, sedangkan MTD didapatkan dari hasil wawancara dengan pemilik aplikasi) dan apabila ada gangguan, disaster recovery team memiliki waktu 30 menit untuk melakukan recovery sehingga kerugian hanya setengah dari rata2-rata frekuensi hits/waktu kerja (8 jam /hari). Penentuan RPO berdasarkan RTO yaitu 15 menit sehingga apabila terjadi suatu disaster maka aplikasi SISPK akan mengalami kehilangan data selama maksimal 15 menit

\section{Rencana Pemulihan}

Backup dan Recovery Database

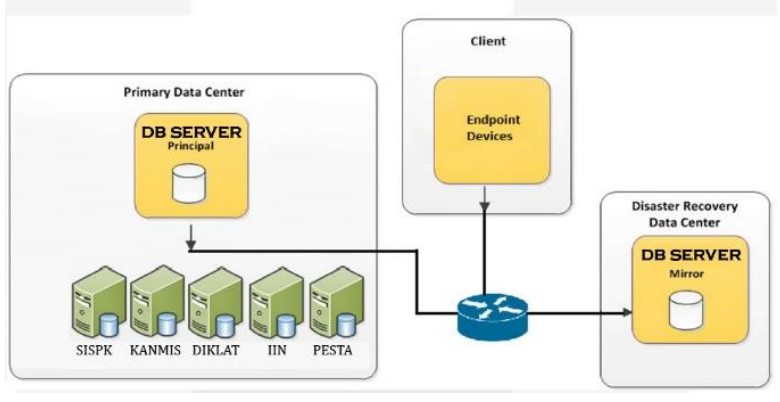

Gambar 10 Database Recovery

Rencana pemulihan database ini adalah Database Mirroring yaitu proses duplikasi database ke lokasi lain (server lain) dengan tujuan agar database tersebut terhindar dari hal yang dapat mengganggu kestabilan database tersebut. Misalnya crash, data tidak bisa di akses, ataupun data tersebut mengalami corrupt.

\section{Backup dan Recovery Application}

Metode P2V memanfaatkan teknologi virtualisasi yang memungkinkan beberapa server berjalan diatas satu server fisik, maka dalam rekomendasi application recovery, metode yang dipilih yaitu P2V

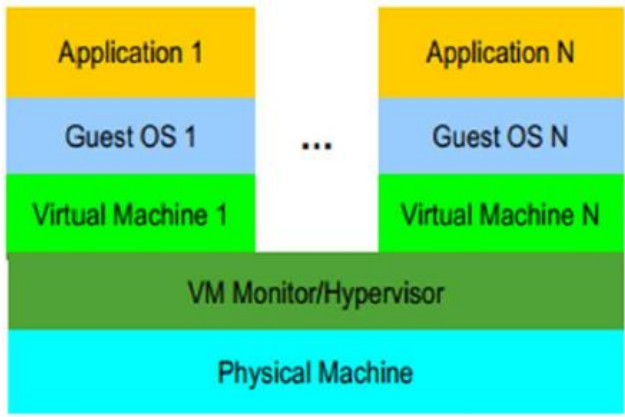

Gambar 11 Application Recovery

\section{Backup dan Recovery Manual}

Proses ini dilakukan secara manual untuk melakukan backup terhadap :

1. File SNI dilakukan minimal 1 (Satu) Bulan Sekali

2. Data Aplikasi dilakukan minimal 1 (Satu) Minggu Sekali

3. Database Aplikasi dilakukan minimal 1 (Satu) Minggu Sekali

4. File Sistem dilakukan minimal 1 (Satu) Bulan Sekali

Data backup disimpan pada lokasi berbeda dari lokasi data awal. 
Lokasi Backup

1. Gd Teknologi 3 (Serpong)

2. Gd SNSU (Serpong)

\section{KESIMPULAN}

Berdasarkan hasil penelitian yang telah dilakukan, maka dapat disimpulkan bahwa:

1. DRP dapat melindungi organisasi dari kegagalan sistem utama

2. DRP dapat meminimalisasi risiko organisasi terhadap penundaan (delay) dalam penyediaan layanan

3. DRP dapat digunakan untuk kehandalan dari sistem yang sedia melalui pengetesan dan simulasi

4. DRP dapat meminimalisasi proses pengambilan keputusan oleh personal/manusia selama bencana.

\section{DAFTAR PUSTAKA}

A. F. U. Fahmawati, (2016) "Faktor-Faktor yang Mempengaruhi Disaster Recovery Plan dan Business Continuity Planning," Universitas Lampung,.

Ariawan Aryaprana, (2000), Perencanaan Disaster Recovery Teknologi Informasi (TI) : Studi Kasus Black Oll Indonesia Inc, MTI-UI

Swanson, M., Bowen, P., Wohl, A.P., Gallup, D., \& Lynes, D. (2010): Contingency Planning Guide for Federal Information Systems., National Institute of Standards of Technology, Gaithersburg.

Pawana, I.G.N.A. (2016): Perancangan Server Dengan Menggunakan Virtualisasi, Load Balancer, Failover, dan Database Replication (Studi Kasus: IKIP PGRI BALI)., Universitas Telkom., Bandung

Wood, T., Cecchet, E., Ramakhrishnan, K.k., Shenoy, P., Merwe, J.v.D., Venkataramani, A. (2012): Disaster Recovery as a Cloud Service: Economic Benefits \& Deployment Challenges., University of Massachusetts Amherst., U
Soetam Rizky W, (2008), Disaster Recovery Planning, Seribu Bintang

Peltier, T.r. (2005). Information Security Risk Analysis, Second Edition. Florida, Auerbach Publications.

Maiwald, E. dan Sieglein, W. (2002). Security Planning \& Disaster Recovery California, Mc. Graw-Hill/Osbor

Tuttle, L.J. (2012): Microsoft SQL Server AlwaysOn Solutions Guide for High Availability and Disaster Recovery., Microsoft.,USA

Brouwer. P. (2011): The Art of Replication., Oracle Corporation 
